\title{
Pragmatic Hedges in Court Trial: Indonesian Case
}

\author{
Nidya Fitri ${ }^{1}$, Ketut Artawa ${ }^{2}$, Made Sri Satywati ${ }^{2} \&$ Sawirman $^{3}$ \\ ${ }^{1}$ School of Islamic Management Education, Stitinu Sakinah Dharmasraya, Padang, Indonesia \\ ${ }^{2}$ Department of Linguistics, Udayana University, Bali, Indonesia \\ ${ }^{3}$ Department of Linguistics, Andalas University, Padang, Indonesia \\ Correspondence: Nidya Fitri, School of Islamic Management Education, Stitnu Sakinah Dharmasraya, Padang, \\ Indonesia.
}

Received: June 3, 2019 Accepted: July 21, 2019 Online Published: July 23, 2019

doi: 10.5539/elt.v12n8p106 URL: https://doi.org/10.5539/elt.v12n8p106

\begin{abstract}
The usage of hedges in trial discourse context is interested to be explored. This paper presents a description of phenomena related to the use of hedges by witnesses and experts in Indonesian court trial. It focuses on the usage of hedges in the form of words, phrases, clauses, and utterances in court trial context. Conversation among participants in court was taken as a corpus of this study. From the corpus, the data were collected in the form of transcription. Three-levels of hedges that classified by Lakoff (1973), Prince, et al. (1982), and Fraser (2010) were used to analyze the data. The analysis was also related to quantity maxim and quality maxim proposed by Grice maxim (1975). This study has shown that the usage of hedges in Indonesian was classified into propositional, approximator, and adjective hedges. They were used to show politeness as well as to hide the real meaning of their utterance.
\end{abstract}

Keywords: pragmatic, hedges, court trial, maxim

\section{Introduction}

Lakoff (1973) defines hedge as "a word that involves fuzziness categories". In the other side, the definition of hedges as a linguistic phenomenon was strongly supported by Meyer (1994). He adopted the definition from Lakoff (1973), Fand (1989), and Brown and Levinson (1978). He stated that linguistic cues of bias are conducted to convey vagueness and tentativeness, and to make a sentence more acceptable to the hearer/reader. Based on that previous study above, this study explores the phenomenon of how hedge influence participants in a court trial. Undeniable, hedge in court trial has been a means to avoid making a definite statement or commitment in a court trial.

Some experts define categories of hedges as considered fuzziness and vagueness that used in a court trial. Meanwhile, in this study, we connected hedges with the principles of Grace Maxim to identify participants answer, whether they telling the truth or just giving a response politely. We believe that this case would be considered by the judge as to the final decision to the defendant. In order to examine the phenomenon, we have conducted this study on a court trial cyanide case.

Cyanide case was the longest crime case in Indonesia. In the court process, there is a lot of language phenomena related to hedges. There are many participants who involved in a court trial, such as a judge, defendant, prosecutors, defense lawyers, witness, and expert. Each participant has their own language style to convince the judge. In this case, we only focused on the use of the hedge by the witness and the expert. We believe that it has influenced the judge's decision in a court trial. We have chosen propositional, approximator, and adjective which were used by participants in the court trial.

\section{Review of Literature}

The previous study quantified hedge as expression and intensifier in translation (Missikova, 2008). Different to the statement of Missikova (2008), Ponterotto (2014) states that hedging strategies are used for discrediting female victim-witness in order to defend their statement in rape trial discourse. Next, this current study is strongly related to Meyer (1994) proposal. Meyer (1994) states that the use of hedge is to indicate scientific claim and lexical hedges in a medical text, especially international Anglo American journals, web server, and popular science magazine. 
Hedges are pragmatic devices in managing information to mitigate a statement or strengthen an idea. The functions of hedges in popular academic writing are equally debated and can also be subdivided into a writer and a reader perspective. Another study that is also relevant to the current study is the study conducted by Tkacukova (2010). He states that hedges are the power of questioning in trial discourse. As Tkacukova (2010) has conducted a study that related to a case study of trial discourse in media interviews and police interrogations, he states that counsels have the power to control all aspect in a trial. Furthermore, he also used discursive tools to restrictive power and pragmatics tools for finding lexical and pragmatic meanings. He adopted the theory of politeness principles.

A hedge, undeniable, can be a parameter to identify a participant's hidden meaning. The statement indicates that the current study is an urgent study. Another urgency of this study relates to the previous study which only claimed hedge as the only tools for analyzing rape trial discourse, academic writing, and pragmatic function. This study shows that hedges can also be used to analyze other crimes cases. As a result, the future linguist can be an expert in a court trial that is by identifying hedge that used by court participants.

Applying Lakoff's and Prince Ideas toward Grace Maxim as a pragmatic function, this study was conducted to answer the following questions; (1) What are the types of hedges that occurred in Indonesian court trial cyanide case? And (2) What are the types of hedges that included in Grice Maxim?

\section{Theoretical Frame Work}

This study applies hedges classification theory proposes by Lakoff (1973) and supported by the theory proposed by Prince et al (1982) and Fraser (2010) which combined into Grice Maxim. Lakoff's hedges (1973) analyzes predicate adjective or predicate nominal namely propositional. They were found in declarative sentence such as sort of, kind of, more or less, roughly, pretty, relatively, somewhat, rather, mostly, technically, strictly speaking, essentially, in essence, basically, principally, particularly, par excellence, largely, for the most part, very, especially, exceptionally, quintessentially, literally, often, more of a than anything else, almost, typically, as it was, in a sense, and in one sense.

Similar to Lakoff's, Prince et al. (1982) divided hedges into three subclasses. They are plausibility shields, approximator, and adaptor. Firstly, Plausibility shields defined as a modal verb and expressed possibility such as 'like' 'probably', 'likely'. etc. As found at the beginning of sequencing court trial proceeding, all participants had to explain their status and position in court trial from previous work, schooling, experience, and give swear and truthful testimony. The next data on discussion section shows some examples of how participant produced other plausibility shields expression such as may, perhaps, maybe, possibly, and maybe. Secondly, Approximator is linguistics aspects that make vague by explaining irrelevant or unavailable sentences called hedges. They stated that hedges appeared in quantity, degree, frequency, and time. For example, roughly, somewhat, quite, often, occasionally. Thirdly, adaptor was related to class membership, for example, somewhat, sort of, almost describable as, some, a little bit, etc. Fraser (2010) has another abbreviation in hedge based on his linguistic analysis. He stated that adverb or adjective hedge is approximately, roughly, about, often, occasionally, and generally.

To create relevant communication to connect to each other and to the main topic of conversion requires and delivers good information and good language. The cooperative principle is introduced by Grice (1975) stated that 'make your conversational contribution such as required, at the stage at which it occurs, by the accepted purpose or direction of the talk exchange in which you engaged'. The four classical Gricean conversational maxims are a quality maxim, quantity maxim, relevance and manner maxim (Grice, 1975; Cruse, 2000; Yule, 1996).

The type of hedges mostly related to participant's ideas as accurately as possible. The participants try to describe their expertise based on their knowledge (expert) and what they have seen in the event (witness). An expression like actually, I know, I think, I'm fairly sure. She gave that impression, etc (Missikova, 2008). It tells the audience to what extent the participants in court trial guarantees the truth of their word or telling the truth. The participant's attempt to provide information which is adequate and necessary is commonly indicated by certain cautious note, such repetitive speech related to quantity maxim. Expression like sort of, kind of, more or less, roughly, pretty, relatively, somewhat, rather, mostly, technically, strictly speaking, essentially, in essence, basically, principally, particularly, par excellence, largely, for the most part, very, especially, exceptionally, quintessentially, literally, often, more of a than anything else, almost, typically, as it was, in a sense, and in one sense (Lakoff, 1973). 


\section{Research Method}

This study delivered the discussion using the descriptive qualitative method. It was conducted at 17 audiovisual sessions which recorded from youtube. The audiovisual was selected by purposive sampling as consider hedges classification (Sugiyono, 2015). To make this study more validity and reliability, researchers used primary and secondary instruments. Primary instruments were (1) Indonesian language transcription orthographically, and (2) result in the observation of combined theory (Edward and Lampert, 1993). Secondary instruments were writing tool to take a note and make a group of the word, phrase, and clause classified into hedges and Grice maxim by using distributional method (Sudaryanto, 2015). In this study, three hedges classification refer to Lakoff (1973), Prince et al. (1982), and Fraser (2010) were combined with Grice maxim (1975).

The reason for choosing hedge classifications and Grice maxim is because it is believed as an effective way to redefine witness and expert statement. The occurrences of hedges are also categorized into pragmatic functions as proposed by Grice maxim theory. In addition, Grice maxim is able to detect witness and expert whether it is a true statement or repetitive statement to convince judge politely.

\section{Results and Discussion}

There were several types of hedges as proposed by Lakoff (1973), Prince et al. (1982), and Fraser (2010). However, combined by Grice maxim, and by looking at the data, there are only two maxims found in this paper. They are quantity maxim and quality maxim.

\subsection{The Combination of the Quantity Maxim Toward Lakoff's and Prince's Perspectives}

In the quantity maxim, the participants in the court trial cyanide case process need to contribute information as required. It is based on the purposes of communication. Witness, expert, and defendant have to give and share enough information to judge, prosecutor, and defense lawyer when they asked a question. In the following description, it is shown that participant produced hedges that refer to quantity maxim

(1) Apa saja kira-kira itu?

'Approximately, what are they?'

(2) Saksi datang kira-kira jam 16.00

'The witness came around 16.00 o'clock (roughly)'

The data above shows the usage of the hedge related to phenomena in the court trial process. It appeared when the participant couldn't define an appropriate answer. Therefore, the participants tried to use another alternative in order to answer or respond to what the judge asked. In example (1) the participant formed hedge Apa saja kira-kira itu? 'Approximately, what are they?'

The question Approximately, what are they?' would not push witnesses to give the correct answer to the judge. In example (2), the participant produced types of hedges 'roughly' found in Apa saja kira-kira itu. Semantically, the meaning was related to 'detail aside' (Lakoff, 1975). Refers to the participant answer, it seems that the witness gave time prediction when judges asked. Another example showed in Indonesia court trial cyanide case is when the appearance of the hedge is closed to the true meaning.

The usage of hedge in words approximately and roughly in example (1) to (2) is related to meaning 'details aside' (Lakoff, 1975). It can be stated that the hedge approximately \& roughly are used to identify witness response. There was another types of hedges such a word 'seperti 'kind of' or 'seems'. They can be see in the following examples.

\section{(3) Tapi sepertinya menejernya yang urus dan mengamankannya}

'But it seems like her manager take care and secure of it'

\section{(4) Kalau memang seperti itu berapa lama kejadian itu anda amati}

'If it would be like that, how long did you observe the accident'

In example (3) and (4), when the participants were in touch in court trial process, the use of hedge 'seems' is found in sentence 'tapi sepertinya menejernya yang urus dan mengamankannya' (but it seems like her manager take care and secured it). It is also found in the word 'like' in 'kalau memang seperti itu berapa lama kejadian itu anda amati' (If it would be like that, how long did you observe the accident). Those two words tend to ignore the self-doubt of their answer.

Based on the example (3) and (4), the participants tried to tell the inaccurate answer to judge. Related to hedge phenomena purposed by LakoffIt, it was equal meaning to "basically and essentially". Next, based on examples 
(3) and (4), the witness produced hedge seems like and like. They tried to tell the inaccurate answer to the judge's question. It identifies that the witness gives information without knowning the real facts.

(5) Kalau kita runut jumlah yang kira-kira seperti ini adalah jumlah sangat besar memberikan reaksi hebat seperti apa yang dilaporkan oleh saksi

'If we roughly refer to the amount of such great reactions as what was reported by witnesses, the number is of course high'

(6) Ketika jumlah yang sangat banyak atau memang yang sangat mematikan begitu...

'When the amount is very much or indeed a very deadly...'

(7) Dengan demikian pendapat ini dengan asumsi bahwa berita acaranya benar ada fakta ada masuk kedalam tubuh korban sebanyak $298 \mathrm{mg}$ yang disebut dalam berita acara

'Thus, this opinion, with the assumption of the investigation, the and based on the report, it is right that there are facts about the amount of 298 as mentioned in the investigation report'

The example (5) is a statement that was given to describe the amount of cyanide that makes great corrosive. Next, example (6) shows an expert opinion when he gave his result analysis to judge. In example (7), judge perceived that there was the fact that cyanide found in the body of the victim. In Example (5) to (7), judges and expert used a lot of repetition of jumlah 'amount' of the cyanide that was drunk by the victim. It can be stated that the expert tried to tell the fact based on his analysis. He has found cyanide in the body of the victim to judge. In Example (5) to (7), the judges and expert used hedge amount of cyanide in gastric of the victim. It could be stated that the expert wanted to tell the fact based on his analysis of the amount of cyanide.

Furthermore, another hedge proposed by Lakoff has also got another expression form such 'principally' (Lakof, 1975), and speech act 'basically' as proposed by Fraser (2010). The following example shows how the judges asked other participants about their competence on how to define the death of victim.

\section{*(8) Saudara mengatakan, Atas dasar apa dia akhirnya meninggal dunia}

'You said that what was the basic to define someone dead?'

In example (8), the participant formed sentence 'Saudara mengatakan, Atas dasar apa dia akhirnya meninggal dunia (You said that what was the basis to define someone dead?). This sentence appeared in the situation when judges asked expertise on how to define someone dead in order to quantify expertise knowledge on how to identify someone dead. It means that the judge tried to get enough information about what was the parameter of the death of victims. In example (8), the judge has formed the basis as hedge refers to expert response and answer. Judge tend to know how expert quantifies someone dead.

\subsection{Plausibility Shields Hedge}

The next phenomena related to the use of hedges is about plausibility shields of hedge. The type of hedge can be seen in the following data.

\section{(9) Saudara bilang tadi sama, tidak mungkin berbeda}

'You said before that it may not be different'

(10) Mungkin pembuatan saya waktu itu terlewat

'Perhaps I missed something what I have done'

(11) Mungkin saya salah, saya tidak terlalu memperhatikan waktu

'May be I'm wrong. I don't really pay attention to the time'

(12) Sangat kemungkinan seperti itu

'It's very possibile'

(13) Sepertinya mungkin keluarga dekatnya terdakwa

'It looks like, $\underline{\text { may be }}$, the family of defendant'

Example (9) to (13) present the usage of the hedge by expertise, judge, and witness. The hedges were used in high frequency. As seen in the above examples, the participants were only able to use the usage of hedge in order to strengthen their statements in the court trial process. In example (9) the participant said 'Saudara bilang tadi sama, tidak mungkin berbeda' (you said before that it may not be different). Next, another expression was used by expert when defense lawyer asked about defendant's friends. 
Based on the example (9) until (13) above, it might be assumed that there was evidence that the participants were able to use of hedge (may not be, perhaps, and possibility, maybe) to strengthen their testimony. It means that the participant tried to share information and express more politeness when answering the question from judges and defense lawyers. Based on the example (9) to example (13) above, it can be seen that participant produces hedge such as may not be, perhaps, may be, and possibility. The purpose of use hedge in their statement is to strengthen their testimony that they tried to give information and make more politeness when answering the question from judges and defense lawyers. Here is another perspective that proposes by Prince's et al. (1982). They state that another type of hedges is expressed in the following example.

(14) Kalau memang seperti itu berapa lama kejadian itu anda amati

'If it would be like that, how long did you observe the accident'

In example (14), sentence 'kalau memang seperti itu berapa lama kejadian itu anda amati' (If it would be like that, how long did you observe the accident) appeared when the judge asked the witness to give clarification about accident time. It performed that the use of hedge of like to explain the certain time of the accident. In example (14) above, the occurrence of hedge in a word like was produced by the judge when he asked the witness where the witness was at the time. It can be determined that the judge asked the witness to give clarification about the time when the accident has happened.

\subsection{Adaptors Hedge}

Next, there is also adaptors hedge. The phenomena of the adaptors hedge are shown in the following examples.

(15) Fakta mengatakan bahwa terjadi korosifyang hebat sedangkan teman terdakwa yang sedikit mencicipi juga mengalami reaksi iritasi pada permukaan lidah

'The fact shows that there was a great corrosive in the victim, while the friend who also tasted a little has also got irritation on the surface tongue'.

Based on the example (15), the participant formed Fakta mengatakan bahwa terjadi korosif yang hebat sedangkan teman terdakwa juga yang sedikit mencicipi juga mengalami reaksi iritasi pada permukaan lidah. (The fact shows that there was a great corrosive in the victim, while the friend who also tasted a little has also got irritation on the surface tongue). There was the use of hedges little to ensure the amount of cyanide come in into victim's friend tested coffee has cyanide inside. It means that the expert tried to give certain fact-based on cyanide symptom to judge when friend's victim also gets tasted the coffee has cyanide.

Based on example (15), the participant tends to use hedge little to perform 'facts'. It might determine that in example (15), there was the use of hedges little to determine the amount of cyanide come into victim's friend when got tested coffee has cyanide inside.

\subsection{The Combination of the Quality Maxim Toward Fraser's Perspectives}

In the quality maxim, the witness in court trial cyanide case process has to tell the true testimony. Witness, expert, and defendant have to give and share enough information to judge, prosecutor, and defense. In the following examples, hedge sure is described when the judge asked a witness and produced hedges that refer to the quality maxim.

\section{(16) Saya tidak yakin untuk waktunya pak}

'I'm not sure at that time, Sir'

In example (16), the participant demonstrated 'Saya tidak yakin untuk waktunya pak' (I'm not sure at that time, Sir). It was stated by a witness as he forgot what he described before to judge. It showed that the word sure was produced by a participant to state his inaccurately time. Meanwhile, the witness notified the judge that he wanted to tell that he did not know about time prediction. In example (16), the participant demonstrated his inaccurate prediction. Meanwhile, the witness noticed the judge that he wanted to tell the fact that he did not know about time prediction.

\section{Conclusion}

This paper demonstrates types of hedges in Indonesia court trial in cyanide case process when the expert and witness gave their response and answer. They have highly produced the use of hedge to give polite response as hedges. On explanation in the discussion, it is found that hedge has a got dominant appearance that constructed meaning. In example (1) to (15), the hedges are appeared and classified into propositional and approximator hedge as quantity maxim. It describes how the experts and witnesses have responded politely to the judge. The form of hedges is rough, seems like, like, amount of, and basic. While in example (16), hedges are classified into 
the adjective hedge as quality maxim. It explains how the witness convinces the judge by telling the true answer. The form of hedges is sure. All hedges can be concluded as linguistics devices to determine quantity maxim. The result has also shown that the usage of hedges in the Indonesian language was classified into propositional, approximator, and adjective hedges.

\section{References}

Cruse, A. (2000) Meaning in Language. An Introduction to Semantics and Pragmatics. Oxford: Oxford University Press.

Edward, J. A., \& Lampert, M. D. (1993). Talking Data: Transcription and Coding in Discourse Research. New York: Psychology Press.

Fraser, B. (2010). Pragmatic Competence: The Case of Hedging. New Approaches to Hedging (pp. 15-34). Bingley, UK: Emerald. https://doi.org/10.1163/9789004253247_003

Fand, R. J. (1989). Deductive Bias in Newspapers: Implications for Teaching ESL. Reading in a Foreign Language, 6(1), 315-321.

Grice, H. P. (1975). Logic and Conversation. In P. Cole, \& J. L. Morgan (Eds.), Syntax and Semantics III (pp. 41-58). New York: Academic Press.

Lakoff, G. (1973). Hedges: A Study in Meaning Criteria and the Logic of Fuzzy Concepts. Journal of Philosophical Logic, 2, 458-508. https://doi.org/10.1007/BF00262952

Lakoff, G. (1975). Hedges: A Study in Meaning and Criteria and The Logic of Fuzzy Concepts. In D. Hockney, W. Harper, \& B. Freed (Eds.), Contemporary Research in Philosophical Logic and Linguistic Semantics (pp. 221-227). Proceedings of a Conference Held at the University of Western Ontario. London, USA: D. Reidel Publishing Company. https://doi.org/10.1007/978-94-010-1756-5_9

Meyer, F. S. (1994). Hedges and Textual Communicative Function in Medical English Written Discourse. English for Specific Purposes, 3(2), 149-70. https://doi.org/10.1016/0889-4906(94)90013-2

Missikova, G. (2008). Maxim Hedges in Literary Text: A Translational Perspective. Discourse and Interaction, $1(1), 73-85$.

Ponterotto, D. (2014). The Risk of Uncertainty: Hedging Strategies in rape trial Discourse. Language and Dialogue, 4(1), 93-111. https://doi.org/10.1075/ld.4.1.06pon.

Prince, E., Frader, J., \& Bosk, C. (1982). On Hedging in Physician-physician Discourse. In R. J. D. Pictro (Ed.), Linguistics and the Professions (pp. 83-97). Proceedings of the Second Annual Delaware Symposium on Language Studies. Norwood, NJ: Ablex.

Sudaryanto. (2015). Metode dan Aneka Teknik Analisis Bahasa: Pengantar Penelitian Wahana Kebudayaan secara Linguistik. Yogyakarta: Sanata Dharma University Press.

Sugiyono. (2015). Metode Penelitian Kuantitatif, Kualitatif, dan $R \& D$. Bandung: Alfabeta.

Tkacukova, T. (2010). The Power of Questioning: A Case Study of Courtroom Discourse. Discourse and Interaction, 3(2), 49-61.

Yule, G. (1996). Pragmatics. Oxford: Oxford University Press.

\section{Copyrights}

Copyright for this article is retained by the author(s), with first publication rights granted to the journal.

This is an open-access article distributed under the terms and conditions of the Creative Commons Attribution license (http://creativecommons.org/licenses/by/4.0/). 